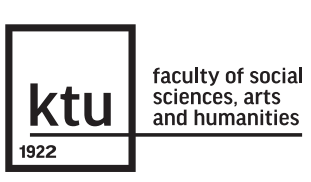

SAL 39/2021

Research Journal Studies about Languages pp. 19-32

ISSN 1648-2824 (print)

ISSN 2029-7203 (online)

DOI 10.5755/j01.sal.1.39.27577
TRANSLATION / VERTIMAS

Culture-specific Items from Ukrainian and Russian Fairy Tales: A Daunting Challenge for Translators
Accepted 08/2021

Crossef http://dx.doi.org/10.5755/j01.sal.1.39.27577
HOW TO CITE: Volovyk, A. (2021). Culture-specific items from Ukrainian and Russian fairy tales: a daunting challenge for translators. Studies about Languages / Kalbu studijos, 39, 19-32. http://doi.org/10.5755/j01.sal.1.39.27577

\title{
Culture-specific Items from Ukrainian and Russian Fairy Tales: A Daunting Challenge for Translators
}

\author{
Ukrainiečių ir rusų liaudies pasakų realijų vertimo iššūkiai
}

\author{
ANNA VOLOVYK, Vasyl Stus Donetsk National University, Ukraine
}

\begin{abstract}
Translation studies of children's literature deserve meticulous attention today not only in the wake of active global publishing activity of books for children but due to the culture-specific information the latter may contain. Fairy tales are usually the first narratives children are introduced to and often these stories with a long-reproduction history reveal some features of national culture that form a child's worldview. From this perspective, the research is set out to identify culture-specific items in fairy tales that originated from oral tradition and to determine what translation procedures should be used and what factors may influence the choice of the translation method. The corpus of the research includes the titles of East Slavic fairy tales limited by culture-specific items and their translations into English and German. Despite the period when translations were made and gender of translators, findings of our research show that in both languages source language-oriented translation procedures prevail in rendering proper names with denotative meaning, and target language-oriented translation methods are dominant for culture-specific common expressions and descriptive elements of proper names. The current research has allowed us to distinguish the factors that may influence the choice of a translation procedure. To this end, a scale of source language- and target language-oriented translation strategies of culture-specific items from fairy tales with the account of target reader's age and genre has been provided for the translators to reveal the efficiency of certain translation procedures. Given the above, the study of culture-specific items in fairy tales requires a greater focus and thus further lines of inquiry are suggested in this paper.
\end{abstract}

KEYWORDS: fairy tale, culture-specific items, translation strategies, translation procedures, source languageand target language-oriented translation.

Introduction

The effective cross-cultural communication is widely considered to be one of the overarching issues today in any sphere of human activity that involves interaction between nations. As Richards and Schmidt claim, the wider the gap between 'cultural conventions' of the communicants, the greater the chance of misunderstanding that is likely to cause 'a total breakdown of communication' (2013, p. 148). Translators are challenged to set a balance between cultural differences and 
to ensure successful intercultural communication. This is especially important when referring to children's audience that gets acquainted with other cultures via fairy tales of their land as well as of the others. Although most of the folkloric motifs and plots 'migrated' from one nation to another there are still many fairy tales that are peculiar only to one nation. Such stories are likely to contain some culture-specific items the meaning of which cannot always be comprehended by source readers without enough encyclopedic knowledge. The situation is far more complicated when these cultural references are to be rendered for children of completely different ethnicity. We initiated this research to determine the efficient translation strategies applied to culture-specific items from fairy tales that come from oral tradition. Although culture-bound elements have been meticulously scrutinized within the translation studies field, there are some research areas that are found to be neglected. The adequate ways of rendering culture-specific items from the titles of Russian and Ukrainian fairy tales into the English and German languages is one of the domains that has not been explored before. Being an under-researched topic, the identification of factors influencing the choice of translation procedure for culture-specific items in the titles of fairy tales also poses a challenge to us. Thus, the two major objectives within the framework of the research are: 1) to study theoretical and practical findings regarding the notion of culture-specific items with the aim of determining the most relevant investigations for our research; 2) to re-examine the traditional approaches to rendering cultural references and to specify the translation solutions that may be effective for a fairy tale genre.

\section{Theoretical Background}

\section{Culture-specific Items in Translation Studies}

Cultural aspects have been widely reviewed within various language investigations. They have received various denominations in Translation Studies. It is claimed that the pioneers of distinguishing the notions related to certain culture were the scholars Vlakhov and Florin (1980) who introduced the term 'realia' (Pažūsis et al., 2014). One can also encounter such names as cultural words (Newmark, 1988), 'cultureme' (Oksaar, 1988), culture-specific concepts (Baker, 1992), cultural bumps (Leppihalme, 2011), culture-specific items (Aixelà, 1996), culture-specific references (Davies, 2003), extralinguistic culture-bound references (Pedersen, 2005), culture-specific material (Ramière, 2006), culture-specific elements (Klaudy \& Heltai, 2020), etc. Despite different denominations, all the terms refer to cultural peculiarities of a nation. For the present study we adopt the term 'culture-specific item' offered by Aixelà (1996) as we consider it to be relevant for the current issue. The term refers to:

textually actualized items whose function and connotations in a source text involve translation problem in their transference to target text, whenever the problem is a product of the non-existence of the referred item or of its different intertextual status in the cultural system of the readers of the target text (Aixelà, 1996, p. 58).

The variety of denominations for culture-specific items (CSI further as the text goes) results in various classifications. Newmark (1988) distinguishes cultural words that belong to five categories: 'ecology', 'material culture', 'social culture', 'organizations, customs and ideas' and 'gestures and habits'. Following Pedersen (2005), Klaudy \& Heltai (2020) emphasize the difference between extralinguistic and intralinguistic culture-specific references. According to Pedersen, 'extralinguistic culture-bound references are expressions pertaining to realia, which are not part of the language, while intralinguistic culture-bound references are those within language system' (2005, p. 2). With the account of the corpus involved into this study, our attention will be focused on extralinguistic CSI that fall into two larger groups singled out by Aixelà (1996): proper nouns and common expressions. Intralinguistic CSI will not be analyzed within the current research.

\section{Translation Strategies of CSI: 'Visible' or 'Invisible' Translators}

A range of translation procedures (Newmark, 1988) used for rendering CSI from various types of the texts and discourses is quite impressive. We gathered findings of the researchers in the table below to reveal some of the differences and similarities regarding the translation of CSI. 
Table 1 Translation procedures of CSI

\begin{tabular}{|c|c|c|c|c|c|}
\hline $\begin{array}{l}\text { Vlahov and } \\
\text { Florin (1980) } \\
\text { (realia) }\end{array}$ & $\begin{array}{c}\text { Newmark } \\
\text { (1988) } \\
\text { (cultural terms) }\end{array}$ & $\begin{array}{c}\text { Baker } \\
\text { (1992) } \\
\text { culture-specific concepts }\end{array}$ & $\begin{array}{c}\text { Aixela } \\
\text { (1996) } \\
\text { (culture-specific item) }\end{array}$ & $\begin{array}{l}\text { Davies } \\
\text { (2003) } \\
\text { (culture-spe- } \\
\text { cific refer- } \\
\text { ences) }\end{array}$ & $\begin{array}{l}\text { Pedersen } \\
\text { (2005) } \\
\text { (extralinguistic } \\
\text { culture-bound } \\
\text { references) }\end{array}$ \\
\hline Transcription & Transference & Use of a loan word & $\begin{array}{l}\text { Repetition / Or- } \\
\text { thographic adapta- } \\
\text { tion (transliteration } \\
\text { and transcription) }\end{array}$ & $\begin{array}{l}\text { Preserva- } \\
\text { tion (form / } \\
\text { meaning) }\end{array}$ & Retention \\
\hline Explanation & $\begin{array}{l}\text { Addition (notes, } \\
\text { additions, glosses) }\end{array}$ & $\begin{array}{l}\text { Use of a loan word } \\
\text { plus explanation }\end{array}$ & $\begin{array}{l}\text { Addition (intratex- } \\
\text { tual / extratextual } \\
\text { glosses) }\end{array}$ & Addition & Specification \\
\hline \multirow[t]{3}{*}{$\begin{array}{l}\text { General- } \\
\text { ization / } \\
\text { Functional } \\
\text { analogue }\end{array}$} & $\begin{array}{l}\text { Functional / } \\
\text { descriptive } \\
\text { equivalents }\end{array}$ & $\begin{array}{l}\text { Use of a more neutral } \\
\text { (less expressive) word / } \\
\text { Use of a more general } \\
\text { word (superordinate) }\end{array}$ & $\begin{array}{l}\text { Universalization } \\
\text { (limited / absolute) }\end{array}$ & $\begin{array}{l}\text { Globaliza- } \\
\text { tion }\end{array}$ & Generalization \\
\hline & Cultural equivalent & Cultural substitution & Naturalization & Localization & $\begin{array}{r}\text { Cultural } \\
\text { substitution }\end{array}$ \\
\hline & Deletion & Omission & Deletion & Omission & Omission \\
\hline $\begin{array}{l}\text { Contextual } \\
\text { synonym }\end{array}$ & Synonymy & & Synonymy & & \\
\hline $\begin{array}{l}\text { Semantic } \\
\text { neologism }\end{array}$ & & & $\begin{array}{l}\text { Autonomous } \\
\text { creation }\end{array}$ & Creation & \\
\hline \multirow[t]{2}{*}{ Assimilation } & Naturalization & & & & \\
\hline & $\begin{array}{l}\text { Recognized trans- } \\
\text { lation }\end{array}$ & & & & $\begin{array}{r}\text { Official } \\
\text { equivalent }\end{array}$ \\
\hline \multirow{10}{*}{$\begin{array}{l}\text { Word-for- } \\
\text { word transla- } \\
\text { tion (calque or } \\
\text { half-calque) }\end{array}$} & Through-translation & & & & $\begin{array}{l}\text { Direct translation } \\
\text { (calque / shifted) }\end{array}$ \\
\hline & Paraphrase & $\begin{array}{l}\text { Paraphrase (related / } \\
\text { unrelated word) }\end{array}$ & Transformation & & $\begin{array}{r}\text { Paraphrase } \\
\text { (paraphrase with } \\
\text { sense transfer } \\
\text { / situational } \\
\text { paraphrase }\end{array}$ \\
\hline & Shift or transposition & & & & \\
\hline & Translation label & & & & \\
\hline & Modulation & & & & \\
\hline & $\begin{array}{l}\text { Reduction and } \\
\text { expansion }\end{array}$ & & & & \\
\hline & $\begin{array}{l}\text { Componential } \\
\text { analysis }\end{array}$ & & & & \\
\hline & $\begin{array}{l}\text { Couplet / triplets / } \\
\text { quadruplets }\end{array}$ & & & & \\
\hline & & & $\begin{array}{l}\text { Linguistic (non-cultu- } \\
\text { ral) translation }\end{array}$ & & \\
\hline & & Illustration & & & \\
\hline
\end{tabular}


We offer the specific color gradation in the table basing on Venuti's bipolar scale (1995). Light green boxes show the translation procedures that are used to foreignize CSI, while dark green boxes cover the translation methods aimed at domesticating CSI. Venuti's scale was modernized by various scholars. Grey color boxes stand for the translation techniques, which are hardly used for rendering CSI as the latter are found in the titles of the fairy tales and reveal what the text is about. We find Ramière's model (2006) defensible with regard to the position of translation procedures as to the degree of cultural mediations:

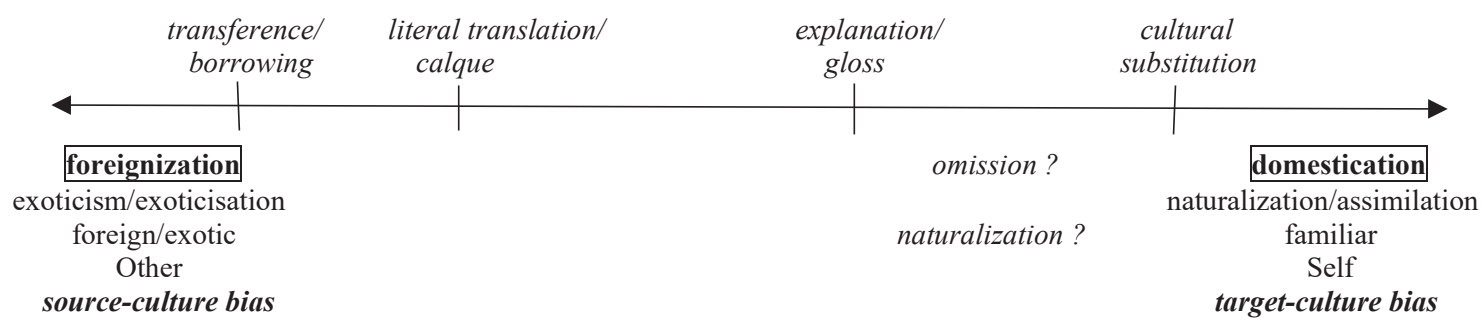

Fig. 1 Ramière's model of typical progression of procedures found in literature

The researcher underlines polarization with each translation procedure that drifts towards one or another pole depending on cultural background of the target audience. Thus, we will use the division of translation procedures into those that are closer to exoticization (source language (SL)-oriented) and those that are aimed at naturalization (target language (TL)-oriented) (Pederson, 2005). In this context, full details on these two poles should be given further. Locus classicus in studying domestication and foreignization as two common translation strategies is the finding of Venuti (1995). According to the scholar, these strategies make the translator either 'visible' or 'invisible' for the target reader/viewer. Domestication on the one hand implies 'ethno-centric reduction of the foreign text to [Anglo-American] target-language cultural values' (Venuti, 1995, p. 20). In a broad sense, this strategy can be employed not specifically to Anglo-American target-language texts, but to any text that includes cultural context. Foreignizing or 'minoritizing' on the other hand 'entails choosing a foreign text and developing a translation method along lines which are excluded by dominant cultural values in the target language' (Venuti, 1997, p. 242). Therefore, preserving some cultural information by foreignizing means that the translator becomes 'visible' for the target audience and at the same time points at something that does not belong to the target culture. Venuti advocates the latter translation strategy as it stands for the signification of cultural difference of any foreign text. In keeping with this approach, it should be emphasized that 'minoritizing' strategy contradicts the concept of 'functional equivalence' formulated by Nida (1964). The latter states that 'a translation of dynamic [functional] equivalence aims at complete naturalness of expression, and tries to relate the receptor to modes of behavior relevant within the context of his own culture' (Nida, 1964, p. 159). However, it cuts down hard on relevance of the original text, as the target audience will not understand cultural background of a certain ethnic group. This is especially true in case of folklore, in particular fairy tales with a wide range of CSI. Fairy tales and CSI in them have been poorly studied within the framework of the abovementioned translation strategies. There is still a considerable ambiguity with regard to the choice of the strategy that will be more effective for rendering CSI from fairy tales. There are those who underpin the role of foreignization (Puurtinen, 1995; Oittinen, 2000) and those who are against domestication (Klingberg, 1986; Zhu, 2016). Reflecting on the translation of children's literature, Klingberg states that removal of cultural elements of the source culture by the elements peculiar to the target one will not broaden the outlook and knowledge of the young reader and spark interest towards foreign cultures (1986, p. 9-10). Moreover, literature review on rendering CSI has shown that when confronted with folklore translation, 'a top priority should be given to the foreignization strategy to reserve the diversity and uniqueness of folklore culture' (Zhu, 2016, p. 23). In support of domestication strategy, Oittinen suggests that "what really matters is how well translations function in real situations, where the "l" of the reader of the translation meets the "you" of the translator, the author, and the illustrator' (Oittinen, 2000, p. 83-84). Ajtony (2017) claims that in some cultures 'domestication is predominant and standard', as the translator must remain invisible 
and make the target text acceptable by the audience (p. 95). Thus, there is still no well-grounded position as to the translation of CSI from children's literature, in particular fairy tales. This research calls into question the faithfulness of both traditional strategies in the context of translating CSI from fairy tales and we are intended to determine the spectrum of translation procedures that will yield adequate perception of the culture-specific text by the target audience.

Methods and Material

The corpus for the research is collected from the titles of East-Slavic fairy tales and their translations into English and German. The data are limited to Russian and Ukrainian fairy tales with the exception of Belarussian due to the lack of their translations into the chosen languages. The total of the titles with CSI collected for the analysis exceeds 500 . However, the amount of the titles with CSI translated into English and German compris-

es only 45 Ukrainian and 64 Russian. Our study also involves several translations of the titles from East-Slavic fairy tales with prevailing of the English variants. Although the chosen data do not form an ample corpus for the research since we realize that it must include a broader collection of CSI, we believe that the analysis of the titles will allow us to make valuable generalizations for further investigations on the subject.

We rely on the principles of the comparative approach aimed at identifying the similarities and differences between translation strategies and procedures used in English and German target text titles of fairy tales. Following Roth (1998), the contextual approach has also benefits for our research as it allows to consider CSI on different levels including the level of language, the level of style/performance and the level of socio-cultural content. In addition, Venuti's model (1995) modernized by Ramière (2006) is regarded as a useful tool in identifying whether cultural differences are preserved or eliminated in the target titles. The current study also refers to the use of the descriptivist approach offered by Toury (1995) resting upon the target-oriented approach. Extending Toury's ideas, we assume that the primary analysis of the target CSI should constitute one of the essential stages in choosing translation strategies.

Results and Discussion

\section{CSI from Russian and Ukrainian Fairy Tale Titles: Newmark's Translation Approaches}

To enable the analysis of translation procedures of CSI from the titles of East-Slavic fairy tales, we will base our research on Newmark's classification (1988) that seems to be well-grounded due to a wide range of procedures it comprises. The classification, therefore, can be applied to various types of texts and discourses. The first translation procedure in Newmark's classification that is clearly SL-oriented is transference. It is defined as 'the process of transferring a SL word to a TL text' (Newmark, 1988, p. 81). This procedure covers transcription and transliteration, and is usually applied to the category of proper nouns. Transference is often used to the proper names from East-Slavic fairy tales:

1 Іванко - цар звірят (Ukrainski Narodni Kazky, 1996, p. 269)

Ivanko, Tsar of the Beasts (Ukrainian Folk Tales, 1985, p. 289)

Iwanko, der König der Tiere (Das Fliegende Schiff, 1981, p. 203)

'Іванко' is a well-known character in East-Slavic culture. It has no descriptive elements; thus, it is retained in the target language functioning as a cultural marker.

The next procedure that is also closer to SL- rather than TL-oriented methods (see Table 1) is addition. Additional information can be given in various forms and can be intratextual or extratextual. It is usually used in combination with other translation methods resulting in a one-unit procedure:

2 Семь Симеонов (Narodnye Russkie Skazki 1, 2008, p. 208)

The Seven Simeons - the Seven Brave Workingmen (Vasilisa the Beautiful: Russian Fairy

Tales, 1966, p. 201)

Die Sieben Brüder Simon (Russische Volksmärchen, 2017, p. 145)

Additional information is given in both of the target titles. Although it does not coincide its function remains the same: added material reveals some details about the referent. In the given examples, addition is combined with transference (English variant) and recognized translation (German variant). 
Moving further the scale of translation strategies, the next procedure that is in the middle between SL- and TL-oriented methods is through-translation (Newmark, 1988). This procedure is known as a word-for-word or calque translation. It can be applied to proper names containing descriptive elements or to common expressions denoting CSI:

3 Елена Премудрая (Narodnye Russkie Skazki 2, 2008, p. 144)

Elena the Wise (Russian Fairy Tales, 1973, p. 545)

Elena die Weise (Russische Volksmärchen, 2017, p. 343)

The source title contains the first name of the character and a descriptive element that is structurally built on the pattern of the family name. Both translations preserve the first name through transference, while the descriptive element loses its relation to the family name due to the use of through-translation and addition of the articles. Despite this change in the source title form, translators manage to render implicit information of the descriptive element that is far more important for the context of the fairy tale.

Among TL-oriented procedures that are closer to domestication rather than foreignization are functional and descriptive equivalents. The latter are subsumed as the procedures of deculturalization of CSI (Newmark, 1988, p. 82). Functional equivalents require the use of a culture-free word that has the same function as the source CSI, while descriptive equivalents are used in case 'when description has to be weighed against function' (Newmark, 1988, p. 83). Translators tend to use functional equivalents for rendering CSI from the titles of East-Slavic fairy tales presuming that this procedure can compensate the loss of the culture-specific meaning of CSI and endow the target word with certain expressiveness:

4 Іван Голик та його брат (Ukrainski Narodni Kazky, 1996, p. 217)

Ivan-Not-A-Stitch-On and his Brother (Ukrainian Folk Tales, 1985, p. 255)

Iwan Hatnichtsan und sein Bruder (Das Fliegende Schiff, 1981, p. 269)

The source CSI contains a descriptive element that performs both informative and culture-marker functions. The translators choose to preserve informative function prioritizing it to culture-specific meaning of the original. And again this decision is quite reasonable, because the descriptive element of the proper name is important for the plot of the fairy tale.

Cultural equivalents take an extreme point on the scale basing on 'naturalization' of CSI. It is used to change cultural reference of one country by cultural reference of another. The decision whether to use this procedure or not should be dictated by the pragmatic purpose of the target text. Within the context of the titles of fairy tales the use of cultural equivalents is rather restricted:

5 Князь Данила-говорила (Narodnye Russkie Skazki 1, 2008, p. 121)

Prince Danila Govorila (Russian Fairy Tales, 1973, p. 351)

Fürst Daniel hat's befohlen (Das Fliegende Schiff, 1981, p. 72)

For conveying the title of the character, the translator of the first example chooses the functional equivalent, while through-translation is used in the German variant. However, we consider it important to emphasize that East-Slavic word 'князь' comes from the German word 'König'. This variant, therefore, could be more effective for rendering the meaning of the source CSI. The given example contains other CSI, in particular the proper name of the character. The latter has a descriptive element that is rendered differently in both translations. The English variant is based on transference, while in German the descriptive component is rendered through the functional equivalent. Moreover, the first component of the source proper name is also conveyed via the use of the cultural equivalent in German. To comprehend adequately the meaning of the original the choice of the functional equivalent for this descriptive component is the right solution. As for the cultural equivalent to the name 'Данила', we assume that this choice should be made basing on the audience it is aimed at. If the readers are too young to understand the cultural reference of the source text, then cultural analogues are an option.

Another translation procedure that can be encountered in the target titles of East-Slavic fairy tales is recognized translation. Though it is not used very common, we believe it must be outlined here as an option for rendering CSI. Recognized translation is considered to be 'official or generally accepted translation of any institutional 
term' (Newmark, 1988, p. 89). In terms of fairy tales, recognized translation is used in case if the title contains proper names of the characters that are well-known in other cultures due to the universal plot of the fairy tale. The brightest example of this is the East-Slavic character 'Колобок' that has its official fairy tale counterparts in English (Johnny-Cake) and German (Pfannenkuchen). The plots of the fairy tales with the abovementioned character almost coincide that indicates their similar roots. Thus, in this case it is possible to talk about the use of recognized translation within the context of fairy tales.

One thing that should be noted with regard to the analyzed translation procedures is that they are often used in combination making couplets. In that way, translators are intended to ensure more adequate rendering of the source CSI. Other procedures distinguished by Newmark (1988) are not relevant for our research and we will not place our attention on them with the account of their rare use.

\section{CSI from Russian and Ukrainian Fairy Tale Titles in English Translations}

Due to the universal use of the English language, the amount of East-Slavic fairy tale translations into this language is larger than into any other. The analysis of the current subject allowed us to compare several translations and to emphasize some extralinguistic factors that might have influenced the choice of the translation procedure. Among these factors are the year when translation was made and gender of the translators. We analyzed the translations of Ukrainian fairy tales published in 1974, 1985, 1989, 1997 and 2017. Most of them were performed by women with the exception of two translations (1974 and 1989). The translations of Russian fairy tales were performed in 1966, 1973, 2011 and 2017 mostly by men. We intended to identify differences in translation procedures applied to CSI within the period of approximately fifty years, and to determine whether gender influenced the choice of a certain translation method. The study of the abovementioned factors did not involve any statistic observations; however, it helped to set the foundations for further investigations.

Analyzing the translation procedures applied to CSI from East-Slavic fairy tales in English diachronically, we discovered that translators did not follow any traditional way of rendering cultural references. Usually, their choice was based on individual decisions:

6 Яйце-райце (Ukrainski Narodni Kazky, 1996, p. 332)

The Magic Egg (Ukrainian Folk Tales, 1985, p. 117)

The Magic Egg (How Ivan Went to See the Sun: Ukrainian Folk Tales, 1989, p. 86)

The Magic Egg (The Magic Egg and Other Tales from Ukraine, 1997, p. 185)

The Magic Egg (Ukrainian Folktales: The collection of folktales from the Ukraine, 2017, p. 187)

All the translators made a solid decision to choose functional equivalents with the purpose to neutralize cultural reference and yet to foreground the function of CSI. That was aimed at explaining the youngest readers the peculiarities of the 'egg' described in the fairy tale. It should be noted that the second translation was made by a male translator, while the other three were made by female translators. This example shows that the choice of translation procedure did not depend on the year of its reproduction, nor on gender.

The results of the research also proved that transference appeared to be the common translation procedure for rendering proper names, in particular the first names, and the year of translation or gender did not influence the translators' decisions:

7 Василиса Прекрасная (Narodnye Russkie Skazki 1, 2008, p. 101)

Vasilisa the Beautiful (Vasilisa the Beautiful: Russian Fairy Tales, 1966, p. 5)

Vasilisa the Beautiful (Russian Fairy Tales, 1973, p. 439)

Vasilisa the Beautiful (Russian Fairy Tales, 2011, p. 29)

Vasilisa the Fair (Russian Fairy Tales. A Choice of Collection of Muscovite Folk-lore, 2017, p. 185)

The first translation of the given example was made by a female translator, while all the others were performed by male translators. The incongruity between variants of the titles in the target language lies in the choice of the through-translation equivalents the meanings of which do not differ much in the context of the fairy tale. Here is one more example of the proper name from East-Slavic fairy tale titles that was rendered by two different translators within the period of almost five decades: 
8 Кощей Бессмертный (Narodnye Russkie Skazki, 2008, p. 244)

Koshchey the Deathless (Russian Fairy Tales, 1973, p. 439)

Koshchei the Deathless (Russian Fairy Tales. A Choice of Collection of Muscovite Folklore, 2017, p. 121)

The only difference between the translations lies in the final letter. Letter ' $i$ ' at the end of the proper name in the second variant is an individual choice of the translator that contradicts the rules of Russian-to-English transliteration, but does not change much the sounding form of the source CSI. In general, both translators applied a couplet procedure (transference with through-translation) to the proper name. Thus, they managed to retain the second descriptive component, while deculturalizing the first one actualized through the lexeme 'Кощей'. This word describes a person with a bony figure (the character of the fairy tale is a gaunt and evil man). We assume that the decision to use transference came from the misconception of the first part of the proper name as a usual first name of the character. On one hand, transference does not allow to preserve local markedness, yet it is the best option to render the title into the target language. Firstly, the title must not be too long and overloaded with additional information. Secondly, all the details about the character, including his gaunt figure, are revealed through the context of the fairy tale. This is sufficient for a child to comprehend implicit information from the title. The role of gender in translation of fairy tale titles was observed through the application of addition. Women who translated the titles tended to give more details assuming that it might unfold the meaning of the CSI:

9 Марья Моревна (Narodnye Russkie Skazki 1, 2008, p. 254)

Marya Morevna the Lovely Tsarevna (Vasilisa the Beautiful: Russian Fairy Tales, 1966, p. 152) Maria Morevna_(Russian Fairy Tales, 1973, p. 439)

Maria Morevna (Russian Fairy Tales, 2011, p. 41)

Maria Morevna (Russian Fairy Tales. A Choice of Collection of Muscovite Folk-lore, 2017, p. 126)

The translators use transference as a common translation procedure for proper names. Nevertheless, the CSI 'Моревна' derives from the name of the Slavic mythical goddess who was connected with rituals of death and revival of the nature. However, the connection with the goddess is not traced in the fairy tale, except for this woman is endowed with divine powers. Thus, we found transference a reasonable decision in this very example. The point of this example is to show that a female translator added information with the purpose of giving some details about the character and making the title more rhythmic, expressive and easy to memorize. Yet we consider the decision to add one more CSI ('Tsarevna') into the title as ineffective since it also requires some explanation. With this in mind, it must be noted that additional information can be justified if it does not interfere with the perception of CSI.

To support our findings with evidence, here is one more example of addition applied by a female translator:

10 Ox! (Ukrainski Narodni Kazky, 1996, p. 399)

Oh (Ukrainian Folk Tales, 1974, p. 32)

Oh! Lord of the Forest (The Magic Egg and Other Tales from Ukraine, 1997, p. 113)

Oh! The Tsar of the Forest (Ukrainian Folktales: The collection of folktales from the Ukraine, 2017, p. 5)

The translations of 1997 and 2017 were performed by female translators and contain additional information about the character. Taking into account that the proper name of the source title does not bear any reference to the familiar objects or characters in the target culture and even the exclamation it originated from is hardly known to the target readers, addition here is an adequate solution. It should be also emphasized that 'Ox' is an Old Slavic mythical being that is considered to be the king of the forest. This also proves that the details added to the target title are justified and help the young reader to anticipate what the fairy tale is about.

There are rare cases of cultural equivalence in rendering CSI from the titles of fairy tales. Moreover, the use of this translation procedure is not restricted to gender:

11 Пан Коцький (Ukrainski Narodni Kazky, 1996, p. 4)

Pan Kotsky, Sir Puss-o-Cat (Ukrainian Folk Tales, 1974, p. 7) 
Pan Kotsky, Sir Puss O’Cat (The Magic Egg and Other Tales from Ukraine, 1997, p. 3)

Sir Cat-o-Puss (Ukrainian Folk Tales, 1985, p. 31)

'Пан' is a Slavic title used to address people to show respect. The title is preserved through transference in the first and second target titles, while the translators add some information which contains the title peculiar to the target audience and some details about the character. The first translation is performed by a male translator, while the second is done by a female translator. The third target title is produced by a female translator as well. She uses cultural substitution of the Slavic title, omits the proper name and compensates that by the functional equivalent that may be also familiar to the target audience through its structural form. We believe that cultural equivalents are a plausible option in this example as the title of the character is not an important detail of the plot. However, we consider the first and second translations too overloaded with additional information that leads to misinterpretation of the Slavic title 'Пан' as a proper name and not a kind of address in the target language.

For making our research more consistent, quantitative analysis was conducted. The percentage of the translation procedures applied to CSI from Russian and Ukrainian fairy tale titles is shown in Tables $\mathbf{2}$ and $\mathbf{3}$ below.

Table 2 Translation procedures of CSI from Russian fairy tale titles into English

\begin{tabular}{l|c|c}
\multicolumn{1}{c}{ Translation procedures } & 37 & $47 \%$ \\
\hline Transference & 17 & $22 \%$ \\
\hline Transference + through-translation & 8 & $10 \%$ \\
\hline Functional equivalent & 4 & $5 \%$ \\
\hline Through-translation & 3 & $4 \%$ \\
\hline Transference + addition & 3 & $4 \%$ \\
\hline Transference + functional equivalent & 2 & $3 \%$ \\
\hline Cultural substitution & 2 & $3 \%$ \\
\hline Descriptive equivalent & 1 & $1 \%$ \\
\hline Deletion & 1 & $1 \%$ \\
\hline Recognized translation & & \\
\hline
\end{tabular}

Table 3 Translation procedures of CSI from Ukrainian fairy tale titles into English

\begin{tabular}{l|c|c}
\multicolumn{1}{c}{ Translation procedures } & 18 & $29 \%$ \\
\hline Transference & 14 & $22 \%$ \\
\hline Functional equivalent & 10 & $16 \%$ \\
\hline Transference + addition & 5 & $8 \%$ \\
\hline Through-translation & 5 & $8 \%$ \\
\hline Transference + through-translation & 3 & $5 \%$ \\
\hline Cultural substitution & 3 & $5 \%$ \\
\hline Descriptive equivalent & 2 & $3 \%$ \\
\hline Deletion & 2 & $3 \%$ \\
\hline Recognized translation & 1 & $1 \%$ \\
\hline Transference + Functional equivalent & 1 & Percentage \\
\hline
\end{tabular}

The results of the quantitative research from the tables prove that transference is the dominant method for rendering proper names from East-Slavic fairy tale titles into English. Transference in combination with through translation is prevailing in the first table due to the large amount of proper names in Russian fairy tale titles containing descriptive components with the latter being translated word-for-word. Dealing with common expressions translators usually use functional equivalents. It should be pointed here that translations of CSI from East-Slavic fairy tale titles are mostly SL-oriented or found somewhere in the middle between foreignization and domestication.

\section{CSI from Russian and Ukrainian Fairy Tale Titles in German Translations}

The analysis of CSI rendered into German was restricted by few translations of East-Slavic fairy tales. The translations of Ukrainian fairy tales involved into analysis were performed in 1975, 1981 and 2012, while Russian fairy tales were analyzed on the basis of translations of 2017. All the translations were performed by women. Nevertheless, for yielding a relatively complete research, German translations were also included into the study. It allowed us to compare translation procedures in languages that belong to the same language family.

German translators of East-Slavic fairy tales also give preference to transference dealing with proper nouns: 
12 Нещасний Данило (Ukrainski Narodni Kazky, 1996, p. 301)

Der unglückliche Danylo (Ukrainische Volksmärchen, 1975, p. 101)

13 Вазуза и Волга (Narodnye Russkie Skazki 1, 2008, p. 87)

Wasusa und Wolga (Russische Volksmärchen, 2017, p. 32)

Within the context of the fairy tale, proper nouns from example 13 refer to the characters in the story; thus, we subsume them to transference rather than to recognized translation of the geographic names.

Transference is usually used in combination with other translation procedures forming couplets to render the meaning of the proper name and its descriptive elements:

14 Телесик (Ukrainski Narodni Kazky, 1996, p. 355)

Telessik, das hölzerne Kindlein (Die Sonnenrose: Ukrainische Volksmärchen, 1966, p. 28)

The given example above shows the use of a couplet (transference with addition) that does not complicate the perception of the title and makes it clear to the target reader who the character is.

Transference with through translation is applied when proper names contain descriptive elements:

15 Трьом-син Борис (Ukrainski Narodni Kazky, 1966, p. 590)

Boris, dreier Väter Sohn (Ukrainische Volksmärchen, 2012, p. 81)

16 Емеля-дурак (Narodnye Russkie Skazki 1, 2008, p. 277)

Emelja, der Dummkopf (Russische Volksmärchen, 2017, p. 173)

One of the advantages of transference of proper names with through-translation of their descriptive components in German is that the target CSI may contain articles that allow indicating the gender of the character, especially when it is difficult for a young reader to comprehend this information.

Apart from transference with through-translation proper names as well as culture-specific common expressions are rendered through functional equivalents:

17 Котигорошко (Ukrainski Narodni Kazky, 1996, p. 162)

Kullerkorn (Die Sonnenrose: Ukrainische Volksmärchen, 1966, p. 77)

18 Сказка о молодце-удальце, молодильных яблоках и живой воде (Narodnye Russkie Skazki 1, 2008, p. 307)

Das Märchen von kühnen Jüngling, dem Lebenswasser und den verjüngenden Äpfeln (Russische Volksmärchen, 2017, p. 187)

The given examples above require some explanations. The translator of the Ukrainian fairy-tale title (example 17) explains the meaning of CSI by applying functional equivalents to two stem-forming parts of the proper name: 'коти' - 'Kuller' in the meaning of 'a ball' and 'горошко' - 'Korn' in the meaning of 'a grain'. To reveal the sense of the CSI from the Russian fairy tale title (example 18), the translator chooses a culturally neutral equivalent that virtually simplifies the perception of the source CSI.

Cultural equivalents are also rather rare in German translations of CSI from East-Slavic fairy tales. Only one example of its use was discovered during the research and that is the same example given in the previous section:

19 Пан Коцький (Ukrainski Narodni Kazky, 1996, p. 4)

Herr Kater Schnurr (Die Sonnenrose: Ukrainische Volksmärchen, 1966, p. 155)

The translator uses the cultural equivalent to the title of the character that in German also shows respect to the person you address. The proper name of the source title is rendered through the functional equivalent that reveals who the character is and what features he has.

Other translation procedures were not used very often; however, the cases of their application were included into the quantitative research given below in the tables: 
Table 4 Translation procedures of CSI from Russian fairy tale titles into Germanh

\begin{tabular}{l|c|c}
\multicolumn{1}{c}{ Translation procedures } & Number & Percentage \\
\hline Transference & 15 & $47 \%$ \\
\hline Functional equivalent & 6 & $19 \%$ \\
\hline Transference + through-translation & 5 & $16 \%$ \\
\hline Through-translation & 4 & $12 \%$ \\
\hline Transference + addition & 1 & $3 \%$ \\
\hline Transference + functional equivalent & 1 & $3 \%$ \\
\hline
\end{tabular}

Table 5 Translation procedures of CSI from Ukrainian fairy tale titles into German

\begin{tabular}{l|c|c}
\multicolumn{1}{c}{ Translation procedures } & 15 & $34 \%$ \\
\hline Transference & 13 & $30 \%$ \\
\hline Functional equivalent & 6 & $14 \%$ \\
\hline Transference + through-translation & 4 & $9 \%$ \\
\hline Through-translation & 2 & $5 \%$ \\
\hline Transference + addition & 1 & $2 \%$ \\
\hline Cultural substitution & 1 & $2 \%$ \\
\hline Descriptive equivalent & 1 & $2 \%$ \\
\hline Deletion & 1 & $2 \%$ \\
\hline Recognized translation & 1 & $1 \%$ \\
\hline Transference + Functional equivalent & 1 & \\
\hline
\end{tabular}

Results of the analysis did not show significant differences between English and German translations. Transference and functional equivalent prove to be the dominant procedures in German target titles. Proper names are usually transferred, while common expressions or proper nouns with descriptive elements become deculturalized through functional equivalents. Other procedures are used less often and depend on a certain type of CSI.

\section{Factors Influencing the Choice of \\ Translation Procedures}

Folklore is considered to be a specific form of transferring culture from generation to generation. Small children get acquainted with orally adapted fairy tales usually told by the adults, while children who are able to read perceive such stories through reading. Therefore, the first factor that influences the choice of the translation strategy lies in the age of the target audience. As Soares notes, 'the purpose of translation should not contradict the idea of childhood' (2018, p. 163). If the target receptor is too young to understand cultural references, then it is preferable to apply TL-oriented translation. Children who are able to read and have some general cultural awareness might prefer SL-oriented strategies that will broaden their outlook about other cultures. However, one thing should be pointed here: if the proper name of the source does not reveal any significant information and has no descriptive components, then translators can retain its original form in the target text. There are always native proper names that might be unknown for the youngest children and sooner or later they learn them. The same applies to foreign proper names that can be also learnt by the youngest target audience. The second factor is genre. Dealing with CSI from fairy tales that originated from oral tradition, translators must base themselves on genre-specific features of such stories. The purpose of translating CSI from literary fairy tales should not contradict the intentions of the author, especially when the latter endows CSI with some additional meanings that must not be missed out. Context may help to realize whether to adapt or retain CSI. Analyzing all the contextual levels, the translator is able to decide what strategy will be more effective. With respect to the abovementioned factors we suggest the scale of translation strategies:

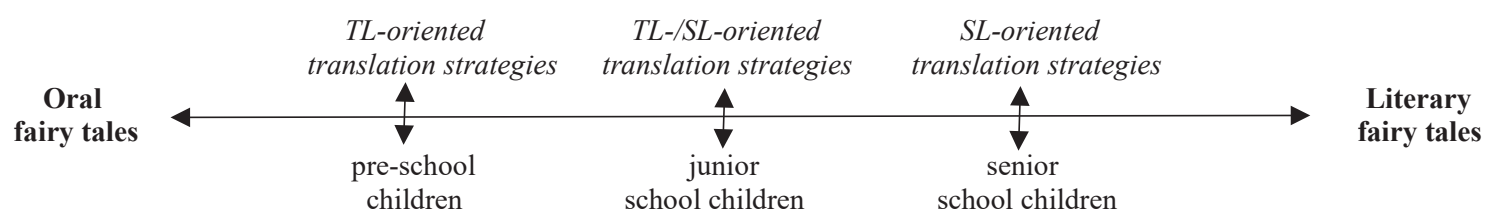

Fig. 2 Translation strategies of CSI from fairy tales 
The scale shows a correlation between translation strategies, age of listeners/readers and genre of fairy tales. Oral fairy tales are usually told to pre-school children as they do not have sufficient reading skills. The purpose of such fairy tales is to introduce children to some moral rules and universal truths. CSI do not perform the dominant function at this stage; thus, their domestication will be more adequate for better perception of the fairy tale by the youngest target audience. The next group of young readers who at this point are able to read is junior school children. The latter get acquainted with both oral and literary tales and broaden their cultural outlook. If translators know that they are to translate for such a target audience, then some additions, glosses, explanations for expanding cultural awareness of children can be made. Senior school children may be more interested in literary fairy tales that contain CSI with the general meaning peculiar to one ethnic group or CSI that are endowed with some additional meanings the author intended to reveal to the readers. Here translators should be aware of the dominant role of context and be ready to apply SL-oriented translation strategies as CSI in literary fairy tales are intentionally used. It must be also emphasized that although age division here can vary depending on the individual abilities of children, the point is in the maturity of thinking and readiness of the brain to comprehend all the implications of CSI.

One more factor that should be taken into account by the translators who deal with the titles is their concise form. One must remember that long descriptions are too ambiguous for perception. The choice of addition or other strategies involving explanation of the meaning must be well-grounded and effective for the titles containing CSI.

\section{Conclusions}

With the corpus and theoretical background involved our research led us to the following conclusions:

$1 \quad$ Based on Venuti's scale of translation strategies and Newmark's classification of translation procedures, our findings show that rendering CSI from East-Slavic fairy tale titles is mostly SL-oriented or somewhere in the middle between foreignization and domestication strategies. Transference is used for proper names bearing denotative meaning, while functional equivalents are preferred in cases of conveying culture-specific common expressions or proper names with descriptive elements. With a few exceptions, our results reveal that the use of cultural equivalents as a purely domesticating procedure is not preferred by translators of CSI from East-Slavic fairy tale titles. There are also cases of couplets that ensure communication of information about the characters.

2 Supported by a quantitative research, results of the study show that English and German translations of CSI do not differ as to the choice of translation procedures. English and German translators use transference, functional equivalents and a combination of transference with through-translation as the primary strategies for rendering CSI from the source fairy tale titles. This results in elimination of cultural identity implicitly expressed through proper and common names. It can thus be seen that foreignizing strategies prevail over domesticating ones.

3 The most important conclusion is that the choice of how to translate CSI from fairy tales much depends on the age of the target audience and genre. Age is one of the most essential factors: the choice of a certain translation strategy should be based on cultural awareness children have. CSI from fairy tales should be adapted for the youngest audience as the moral function of the story is far more significant than the expression of foreign culture peculiarities. When children grow older they are able to perceive the text as well as CSI from fairy tales differently; thus, SL-oriented procedures are more preferable. Genre should not be overlooked either. Dealing with literary fairy tales translators must be aware that CSI in such stories are used intentionally; therefore, TL-oriented procedures might be ineffective in this case. It must be emphasized that although our investigation concerned CSI from the titles of fairy tales we consider that the results of the research can be applied to CSI precisely from the texts of Russian and Ukrainian fairy tales translated into German and English. We are currently in the process of investigating this question in order to confirm our previous findings. We also believe that studying translations of fairy tales diachronically and with account of gender of translators will spur some challenging issues and help to come closer to the solution of the problem regarding CSI translation. 


\section{References}

1 Aixelá, J. F. (1996). Culture-specific items in translation. In Álvarez, R., \& Vidal, C. Á. (eds.) Translation, Power, Subversion. Cleveland/ Bristol/Adelaide: Multilingual Matters. pp. 52-78.

2 Ajtony, Z. (2017). Taming the stranger: domestication vs foreignization in literary translation. Acta Universitatis Sapientiae: Philologica 9(2), 93-105. https://doi. org/10.1515/ausp-2017-0020

3 Baker, M. (1992). In Other Words. A Coursebook on Translation. London: Routledge. https://doi.org/10.4324/9780203327579

4 Das Fliegende Schiff: Ukrainische Volksmärchen. (1981). Kiew: Verlag Dnipro.

5 Davies, E. E. (2003). A goblin or a dirty nose? The treatment of culture-specific references in translations of the Harry Potter book. The Translator, 9(1), 65-100. https:// doi.org/10.1080/13556509.2003.10799146

6 Die Sonnenrose: Ukrainische Märchen. (1966). Berlin: Verlag Kultur und Fortschritt.

7 How Ivan Went to See the Sun. (1989). Kiev: Dnipro Publishers.

8 Klaudy, K., \& Heltai, P. (2020). Re-domestication, repatriation, and additional domestication, in cultural back-translation. Across Language and Cultures, 21(1), 43-65. https:// doi.org/10.1556/084.2020.00003

9 Klingberg, G. (1986). Children's fiction in the hands of the translator. Studia psychologica et paedagogica. Series altera LXXXII. Lund: CWK Gleerup.

10 Leppihalme, R. (2011). Realia. In Y. Gambier, \& L.V. Doorsler (eds.), Handbook of Translation Studies 2, pp. 126-130. Amsterdam/ Philadelphia: John Benjamins. https://doi. org/10.1075/hts.2.rea1

11 Narodnye Russkie Skazki A.N. Afanasyeva v 5 tomakh: tom 1 [National Russian Fairy Tales collected by A.N. Afanasyev in 5 volumes: volume 1]. (2008). Moskva: TERRA Knizhnyi Klub.

12 Narodnye Russkie Skazki A.N. Afanasyeva $\checkmark 5$ tomakh: tom 1 [National Russian Fairy Tales collected by A.N. Afanasyev in 5 volumes: volume 2]. (2008). Moskva: TERRA Knizhnyi Klub.

13 Ukrainian Folktales: The collection of folktales from the Ukraine consists of one book with 27 folktales. (2017). CreateSpace Independent Publishing Platform.

14 Newmark, P. (1988). A Textbook of Translation. London/New York: Prentice Hall.
15 Nida, E. A. (1964). Toward a Science of Translating. With Special Reference to Principles and Procedures Involved in $\mathrm{Bi}-$ ble Translating. Leiden: Brill. https://doi. org/10.1163/9789004495746

16 Oittinen, R. (2000). Translating for Children. New York \& London: Garland Publishing, Inc.

17 Oksaar, E. (1988). Kulturemtheorie. Ein Beitrag zur Sprachverwendungsforschung. Göttingen: Vandenhoeck \& Ruprecht.

18 Pažūsis, L., Maskaliūnienè, N., Darbutaitè, R., Klioštoraitytè, R., Mankauskienè, D., Miškinienè, I., \& Paura, M. (2014). Vertimo studijų žodynas. Vilnius: Vilniaus universitetas.

19 Pedersen, J. (2005). How is culture rendered in subtitles? In Proceedings of the Marie Curie Euroconferences MuTra: Challenges of Multidimensional Translation, Saarbrücken 2-6 May 2005 (pp. 1-18). Available at: https://www.euroconferences.info/proceedings/2005_Proceedings/2005_Pedersen_ Jan.pdf [Accessed September 2019].

20 Puurtinen, T. (1995). Linguistic Acceptability in Translated Children's Literature. Joensuu: University of Joensuu.

21 Ralston, W.R.S. (2017). Russian Fairy Tales: A Choice Collection of Muscovite Folk-lore. Canton: Pinnacle Press.

22 Ramière, N. (2006). Reaching a foreign audience: Cultural transfers in audiovisual translation. The Journal of Specialised Translation 6, 152-166. Available at: https:// jostrans.org/issue06/art_ramiere.php [ACcessed September 2019].

23 Richards, J. C., \& Schmidt, R. W. (2013). Longman Dictionary of Language Teaching and Applied Linguistics (4th ed.). New York, NY: Routledge. https://doi. org/10.4324/9781315833835

24 Roth, K. (1998). Crossing boundaries: the translation and cultural adaptation of folk narratives. Fabula 39(3-4), 243-255. https:// doi.org/10.1515/fabl.1998.39.3-4.243

25 Russian Fairy Tales (Illustrated). (2012). Cambridge: The Planet.

26 Russian Fairy Tales. (1975). London: Sheldon Press.

27 Russische Volksmärchen. (2017). Köln: Anaconda Verlag.

28 Soares, C. (2018). The purification of violence and the translation of fairy tales: a corpus-based study. Ilha do Desterro A Journal of English Language, Literatures in English and Cultural Studies, 71(3), 161-178. https:// doi.org/10.5007/2175-8026.2018v71n3p161 
29 The Magic Egg and Other Tales from Ukraine (World Folklore Series). (1997). Englewood: Libraries Unlimited, Inc.

30 Toury, G. (1995). Descriptive Translation Studies and Beyond. Amsterdam/Philadelphia: John Benjamins Publishing. https:// doi.org/10.1075/btl.4

31 Ukrainski narodni kazky [The Ukrainian folktales]. (1996). Kyiv; Irpin: Perun.

32 Ukrainian Folk Tales. (1974). Kiev: Dnipro Publishers.

33 Ukrainian Folk Tales. (1985). Kyiv: Dnipro Publishers.

34 Ukrainische Volksmärchen. (1975). Kiew: Verlag Dnipro.

35 Ukrainische Volksmärchen. (2012). Norderstedt: BoD - Books on Demand.
36 Vasilisa The Beautiful: Russian Fairy Tales. (1966). Moscow: Progress Publishers.

37 Venuti, L. (1995). The Translator's Invisibility. A History of Translation. London: Routledge. http://dx.doi.org/10.4324/9780203360064

38 Venuti, L. (1997). The American tradition. In Baker, M., \& Saldanha, G. (Eds.), Routledge Encyclopedia of Translation Studies (pp. 305-315). London \& New York: Routledge.

39 Vlakhov, S. \& Florin, S. (1980). Neperovodimoe $v$ perevode [Untranslatable in Translation Studies]. Moskva: Mezhdunarodnye otnoshenija.

40 Zhu, L. (2016). A study of translation strategy of folklore in Biancheng. Studies in Literature and Language, 12(4), 17-23. http:// dx.doi.org/10.3968/8345

\section{Santrauka}

\section{Anna Volovyk. Ukrainiečių ir rusų liaudies pasakų realijų vertimo iššūkiai}

Vaikų literatūros vertimo tyrimas šiuo metu vertas ypatingo dèmesio ne tik dèl to, kad visame pasaulyje aktyviai leidžiamos knygos vaikams, bet ir dèl to, kad jose gausu kultūriškai paženklintos leksikos. Iprastai pasakos - tai pirmosios istorijos, su kuriomis vaikus supažindina suaugusieji, ir dažnai tokiose iš kartos ị kartą perduodamose istorijose atsiskleidžia tautinès kultūros bruožai, formuojantys vaiko pasaulėžiūrą. Atsižvelgiant i tai, šio tyrimo tikslas yra atpažinti tas realijas liaudies pasakose, nustatyti jų vertimo būdus, taip pat ištirti veiksnius, turinčius jitakos tam tikros vertimo strategijos pasirinkimui. Tyrimo medžiaga buvo Rytụ slavụ pasakụ pavadinimai, kuriuose yra kultūriškai pažymètų vienetų, taip pat jų vertimai į anglų ir vokiečių kalbas. Taikant diachroninị ir lyčių lygybe paremtą požiūri i liaudies pasakų realijų vertimo metodụ tyrimą, nustatyta, kad abiejose tikslinèse kalbose, siekiant perteikti denotacinę reikšmę turinčius tikrinius vardus, buvo naudojamos svetinimo (foreinizacijos) strategijos, tuo tarpu savinimo (domestikacijos) strategijos vyravo ten, kur buvo siekiama perteikti kultūriškai specifines išraiškas ir apibūdinamuosius tikrinių vardụ komponentus. Atsižvelgiant ị tikslinès auditorijos amžių ir pasakos žanrus sukurta vertimo strategijų naudojimo skalè, leisianti supaprastinti vertimo strategijų pasirinkimą. Apibendrinant reikia pažymèti, kad šią temą reikia nagrinèti giliau, todèl darbe yra numatyti tolesni realijų pasakose tyrimo keliai.

\section{About the Author}

\section{ANNA VOLOVYK}

$\mathrm{PhD}$, Assistant professor at the Theory and Practice of Translation Department, Vasyl Stus Donetsk National University, Ukraine

\section{Research interests}

Literary Translation Studies, translation of children's literature, culture-specific items in translation, cross-cultural communication

\section{Address}

4, Akademika Yanhelia St., Vinnitsia, Ukraine, 21000

E-mailvolovyk.anna@gmail.com 